\title{
A Review of To Market, To Market by Ivy Higgins
}

\author{
Marjorie Downie ${ }^{1}$ \\ The College of The Bahamas
}

To Market, To Market, Ivy Higgins' debut novel, published by Robbie Dean Press in 2010, is the story of Calvin-Joe, a "big-foot" boy child born to Ma Lou, his feisty mother and her much older husband, Lazarus, in the little district of Bottom Patrick, a rural area in the hills of Manchester, Jamaica. The story is set in the turbulent 1960s when J. F. Kennedy was President of the United States. Ma Lou is the quintessential Jamaican mother, poor but vibrant, a pillar of her church and community who fights tirelessly for her beloved boy child, and does everything in her power to save him from stagnating - or worse-in Jamaica.

The community is as much a character in this novel as are Ma Lou, Calvin-Joe, his girlfriend Lucy-Mae, his father Lazarus, and Marrah, Ma Lou's nemesis. The people are always "clackclacking” as Roger Mais (1954) put it, constantly talking about one another, events in the neighbourhood, commenting on everyone's failings, successes, life events, moral turpitude and everything under the sun. The juiciest pieces of gossip are chewed, swallowed and digested; everything that happens is tirelessly discussed and analyzed. The tongues clack when Calvin-Joe gets one of the coveted farm work cards. They clack even more delightedly after Lazarus dies, and Bertie, her suitor, starts to visit Ma Lou at all hours of day and night. The description of the rural countryside, its traditions and its denizens is a strong point of the novel.

Religion is an integral part of village life. The church is the centre of the people's activities, a cultural and social hub where the pastor wields the patriarchal power to deal with individuals who contravene the admonitions of the Bible. He is able to pass judgment on people's private activities such as when he warns Ma Lou about the consequences of her relationship with Bertie. Ma Lou's rebellion against her church is therefore a significant act, as it carries serious social consequences. Though in marrying Bertie she embraces life and rejects the stultifying effects of a church which seeks to straight-jacket its members, she misses it greatly. It gave her importance, power and influence, which she enjoyed. Eventually, the Church "benched" hershe is no longer allowed to be in the forefront of church activities. Nevertheless, Ma Lou ignores the church's strictures and, at the age of 48 , rebels and marries Bertie, whereupon she is declared a "backslider" - a word with the most negative connotations - and excommunicated. She then becomes a social pariah, a woman on the margins. Only her strong personal resources enable her to withstand and survive this rejection.

The community not only comments on but also participates in the important life events of its members. When Calvin-Joe goes on his first trip to America, no fewer than twenty people accompany him to the airport. His departure is a community effort: Lazarus sold a pig, the godparents sold some chickens, and an offering was taken up in church to defray the expense of his trip. This incident is not only humorous but is also a tribute to the strong spirit of communality that marked social relations in the rural Jamaican

\footnotetext{
${ }^{1}$ Marjorie Downie, Associate Professor, School of English Studies, The College of The Bahamas, P.O. Box N-4912, Nassau, Bahamas.

E-mail: mdownie@cob.edu.bs

How to cite this article in APA ( $6^{\text {th }}$ ed.) style: Downie, M. (2010). A review of To Market, To Market by Ivy Higgins [Book review]. The International Journal of Bahamian Studies, 16, 102-105. https:// doi.org/10.15362/ijbs.v16i0.130
}

(c) M. Downie, 2010. Journal compilation @ The International Journal of Bahamian Studies, 2010. 
countryside in the past and which still, to some extent, remains evident today.

Calvin-Joe's departure for the promised land of the United States marks To Market, To Market as a novel of migration, as Calvin-Joe, on the cusp of manhood, and enmeshed in the murderous anger and frustrated ambition that makes of good boychildren, murderers and jailbirds at a young age, migrates to America, the vaunted land of opportunity from which successful children are expected to return periodically with the trappings of success to regale their parents and families with lavish gifts. Ma Lou, divining his descent into murderous rage, seeks to save her child by getting him one of the coveted farm work cards for which Jamaicans pulled strings and called in favours. To do this, she uses all her feminine wiles on Bertie, who has some influence with the man who distributes the cards. The humble nature of Calvin-Joe's ambitions at first-to build his mother a new pit-toilet-gradually expands to building her an entirely new house. This is one of the fondest dreams of the Jamaican immigrant- to build a house in the beloved homeland to which to return in the evening of life. With his earnings from boxing, Calvin-Joe is able to build Ma Lou, not just a refurbished, but a completely new house-rather fancifully compared to 132 Downing Street-with two drawing rooms, two indoor toilets, a bathroom inside the bedroom, tiled floors and, wonder of wonders, a "whole room" for her clothes. The young Jamaican immigrant is almost required to make good abroad and return to help parents. This reverence for parents, especially mothers, is part of the Jamaican/Caribbean ethos.

Later, the migrants-Buddie of Dominica, and Calvin-Joe-talk about the poverty and wasted potential of their homelands, where bright boys like Donovan, even if they got a government scholarship, were unable to take it up because their parents could not find "lunch money an uniform an bus fare". Their dreams of success focus on athletics, often the sole option for black men in America who want to escape the relentless cycle of poverty-wealth via football, track and field, or boxing. Soop manages to get Calvin-Joe legal status through a "business" marriage. Eventually he gets a job at Georgia Tech as a janitor where he reads Mills and Boon, a strange choice of reading material for a male-maybe a leftover from his romantic feelings for Lucy-Mae. Like many immigrants with dreams of making it in their new homeland, he eats cheap foods such as white rice, bread and sardines to save money.

The ways in which migration derails people's lives are sadly explored in the stories of immigrants. For example, Lucy-Mae and CalvinJoe obviously have strong feelings for each other yet Calvin-Joe, in exile, has affairs with other women while paradoxically always pining for the girl left in Jamaica. Why, one might ask, does he not marry her and bring her to America? The thought does occur to him but his marriage of convenience to an American puts paid to that dream and by the time this marriage is over, lifenot to mention assorted other women-has intervened. When she hears of Calvin-Joe's engagement to Hope Manning, Lucy Mae, on the rebound, marries 57-year-old Uncle Bredda (Ma Lou's brother and Calvin-Joe's uncle). Ironically, Lucy-Mae seems set to follow in the footsteps of Ma Lou, forgoing the sweetness of marrying her first love for the security of marriage to an old man, just when Lazarus' death liberates Ma Lou from the frustrations of such a marriage. The story of Alice exemplifies the plight of the immigrant who can't return home for important events because he or she is hiding from the authorities. Alice is unable to attend her beloved Auntie's funeral in Jamaica.

The exploitation of farm workers is explored in the descriptions of Calvin-Joe's early experience in America. At Hastings Farm where he meets Buddie, who later becomes a loyal friend, the farm workers rise at 4:30 am to begin the day's grueling labour. The workers are exploited and deliberately made dependent on the credit system that soon makes pseudo-serfs of them. Later, when Calvin-Joe and Buddie decamp to another farm, the supervisor, Soop, is a Bahamian from Cat Island. The farms are a graveyard of broken dreams, suffering and brutality for numerous Caribbean and South American migrants. Even so, many used farm work as a stepping-stone to legal status in the United States. A few, like Debbie's grandfather, Mr. Rolle, who came to the United States from the Bahamas on the Contract, make good so that Debbie, who becomes Tex's new girl, is comfortably middle-class. 
The title is a bit of a puzzle. However, there is one small episode that throws some light on it. Ma Lou's granddaughter sings it with Lazarus, after trying to puzzle out the meaning of the European fairytale about Red Riding Hood, which disturbs her. She seems to take comfort in the familiarity of the Jamaican playground song, "To market, to market to buy a fat pig, a fat cow, a fat hog, etc". Does this imply a rejection of European cultural traditions and an embracing of indigenous culture? Certainly, selling provisions in the market sustained many a rural family, and the rhythms of village life tended to centre on market days in the larger towns on which people converged to buy and sell various home-grown vegetable and animal products. To Market, to Market is marked by nostalgia for these old ways.

Higgins' use of language is authentic, conveying the rhythms and texture of rural Jamaican language and life. An expression like "kitchen bitch" (for the lamp used to provide illumination and to light wood stoves) is one example. The deep rural patois of Ma Lou's description of what her mother would have done to deal with a nail in the foot- "put some pork skin and peppa leaf on dat...and by de time yuh seh 'gun fiah', problem solve" - is another. This illustrates the Jamaican peasants' capacity to produce the most startling and fresh images. "By de time yuh seh 'gun fiah"” indicates how quickly the illness is dispatched when the remedy is used. Their use of pastoral images is also exemplified in expressions like "dem noh carry young chocho like im goh a Merica fi goh cut cane”. This expresses CalvinJoe's youthfulness and unsuitability for the grueling task of cane-cutting by comparing him to an immature vegetable. At the funeral of Lazarus, Calvin-Joe's helicopter is said to sound like "a train going over Melrose Hill", one of the mountains that slope away from the parish capital of Manchester, Mandeville. Such a train would labour to climb the steep incline, which portrays the sound made by the helicopter. After CalvinJoe brings the "white girl," Catherine, to his father's funeral, he is described as a "roast breadfruit," black on the outside and white on the inside, a man who has betrayed his race. When Lucy Mae transforms herself into a girl with straightened hair and makeup, her mouth is compared to an "otaheite apple"-a Jamaican fruit whose brilliant red exterior aptly signals the colour of the lipstick Lucy Mae now wears, while for those familiar with the fruit, its juiciness signals not just the desirability of her lips but her youth and nubility.

Higgins includes many typical quirks of Jamaican/Caribbean life such as the mispelling of children's names on their birth certificates and the use of nicknames or "pet" names. One particularly humorous example is the often-told cautionary tale of Bubba White: "The first girl was registered Martha White. The second one was Carolyn Whyte. The third one was Daisy Wite. The fourth was Susan White, and worst of all, the only boy was Jonathan Whyte.” Ma Lou herself relentlessly rejects all efforts to call her child Blackie, Big Foot, and Lang (Long) Teeth so Calvin-Joe, unlike many in his district, retained his given name.

The sometimes savage class distinctions in Jamaican society are explored through the experiences of Tex, the smart young Jamaican who falls in love with an upper St. Andrew girl aptly named "Perfect", an experience which deeply bruises him. Higgins seems to argue that The Bahamas is-or was-similarly tainted. Soop, in his youth, fell in love with his Government High schoolmate who lived in Shirlea. However, though they are of similar intellectual accomplishments, the unwritten laws of class relations preclude any closer ties between them. Soop, a lower-class boy brought up by his grandparents, is only too aware of this, so he never declares his love for her though her image haunts him even much later in life.

Another "typical" part of Caribbean life is the teenager who gets pregnant. Ma Lou's eldest daughter takes this role to much hullabaloo and gossip in the village. Everyone has something to say about it but in the end the baby, Little Kimmy, becomes her grandfather Lazarus' "Little Jewel", a beloved member of the household. Like many such children, she is raised in her grandmother's house. The church may frown on such out-ofwedlock births but the community takes it in stride, providing the child and her mother with the support and love they need. This approach to the wisdom of the folk is reminiscent of such early West Indian novels as Banana Bottom (1933). 
Drugs and violence also make an appearance in this novel through Brian, a drug-addled former boyfriend of Hope Manning, Calvin-Joe’s fiancée. Hope has moved west to avoid the creepy Brian but he stalks and finds her again. On a trip to Nassau, Bahamas, Calvin-Joe reconnects with Hope, whom he had met casually some time before. They had a good time together in Nassau and begin a long-distance relationship which in time leads to a marriage proposal. The ill-fated relationship comes to an abrupt end when Brian's goons attack Calvin-Joe. The savagely ironic ending has been presaged by early violent episodes and Calvin-Joe's nightmares of murder and hanging. And so the novel comes full circle.

\section{REFERENCES}

Mais, R. (1954). Brother man. London: Jonathan Cape.

McKay, C. (1933). Banana bottom. New York, NY: Harper \& Bros. 